\title{
Antimicrobial Activity of Five Plant Extracts and Synthetic Fungicide in the Management of Postharvest Pathogens of Yam (Dioscorea Rotundata Poir) in Storage
}

\section{Gwa VI1,2*, Nwankiti $\mathrm{AO}^{1}$ and Hamzat $0 \mathrm{TH}^{3}$}

${ }^{1}$ Department of Crop and Environmental Protection, Federal University of Agriculture, Nigeria

2Department of Crop Production and Protection, Federal University, Nigeria

${ }^{3}$ Crop Research Program, Federal University of Agriculture, Nigeria

\section{Research Article}

Volume 3 Issue 1

Received Date: July 07, 2018

Published Date: August 17, 2018

DOI: $10.23880 /$ oajmb- 16000128

*Corresponding author: Gwa VI, Department of Crop and Environmental Protection, Federal University of Agriculture, PM B 2373 Makurdi, Nigeria, Email: igwa@fudutsinma.edu.ng

\section{Abstract}

Crude extracts leaves of Azadirachta indica A. Juss. (neem), Nicotiana tabacum Linn. (Tobacco), rhizomes of Zingiber officinale Rosc. (Ginger), leaves of Carica papaya Lam. (pawpaw) and seeds of Piper guineense Schumach. (Black pepper) were tested at $30 \mathrm{~g} / \mathrm{L}, 60 \mathrm{~g} / \mathrm{L}$ and $90 \mathrm{~g} / \mathrm{L}$ as well as mancozeb at $4 \mathrm{~g} / \mathrm{L}, 8 \mathrm{~g} / \mathrm{L}$ and $12 \mathrm{~g} / \mathrm{L}$ concentrations against Aspergillus ochraceus in vitro. Rotted yam tubers were collected from farmers' barns forth nightly for four times. Treatments were replicated three times and completely randomized. Data were subjected to analysis of variance (ANOVA) and means were separated using Fisher's least significance difference (LSD). Mycelial growth of A. ochraceus was inhibited by these extracts. Percentage growth inhibitions at $30 \mathrm{~g} / \mathrm{L}$ ranged from $40.19 \%$ (N. tabacum) to $51.95 \%$ ( $P$. guineense) while percentage growth inhibitions at $60 \mathrm{~g} / \mathrm{L}$ ranged between $57.47 \%$ ( $N$. tabacum) and $70.56 \%(P$. guineense). The highest inhibitions were recorded at $90 \mathrm{~g} / \mathrm{L}$ with a range between $66.22 \%$ (A. indica) and $74.15 \%(P$. guineense). Mancozeb was found to be the best in inhibiting the mycelial growth of A. ochraceus in culture irrespective of concentration and duration of incubation with $100 \%$ growth inhibition. The extracts and mancozeb were sprayed on yam tubers before storage for five months. Stored tubers showed a decay reduction index of 1.00 (mancozeb), 0.93 (A. indica) and 0.83 (P. guineense and Z. officinale) in the first year of storage indicating a reduction in rot by $100 \%, 93 \%$ and $83 \%$, respectively. The extracts were comparatively less effective in the second year of storage. It is therefore, concluded that plant extracts could be used in management of rot causing organisms of yam in storage since they are environmentally safe, cheap and easily available compared with synthetic chemicals. 


\section{Open Access Journal of Microbiology \& Biotechnology}

Keywords: Antimicrobial; Aspergillus ochraceus; Inhibition; Mycelial; Plant extracts; Post harvest

\section{Introduction}

Yam (D. rotundata) production and consumption is mostly in West Africa, East Africa, the Caribbean, South America, India and South East Asia [1,2]. Nigeria has the highest production record of 38.92 million metric tonnes of yam tubers annually $[3,4]$. Production of yam is constrained by several factors such as high cost of production, pests and diseases. Pathogenic microorganisms including bacteria, fungi and viruses attack yams at all stages of growth and also during storage of tubers [5-10]. These constraints are responsible for reduction in growth, tuber formation and development as well as tuber quality during storage [11]. Though a yam tuber naturally has a periderm that microorganisms cannot breach, it is easily wounded by other pest organisms such as insects, rodents, nematodes and even man during weeding, harvesting and post-harvest handling. These wounds serve as entering points to these rot inciting microorganisms [12]. Losses due to rot organisms were estimated to be as low as $10-15 \%$ in the first three months of storage. Okigbo, Arinze and Okigbo, et al. [13-15] estimated losses to diseases in storage to be as high as $50 \%$ of the yam tubers produced in Nigeria. According to Sadiku and Sadiku [16] rot caused by pathogenic organisms may be exacerbated due to challenges in climate change. Various types of synthetic fungicides have been used to control different types of plant diseases in different crops. The major disadvantages are the development of resistance to many of the currently used chemicals in circulation, pollution of soil, ground and surface water as well as the atmosphere $[17,18]$. Biological control based on use of plant products as well as use of antagonists is the popular alternative to the use of synthetic fungicide control [19-23]. Some plants are known to synthesize phytochemical compounds with antimicrobial potencies and are used successfully in the control of diseases in humans and crops such as yam, cassava, tomato, cowpea, rice, etc. $[10,24,25]$. The advantages of using these natural plant products are enormous and include; little or no mammary toxicity, local availability, biodegradability and simple preparation procedures $[9,26]$. The aim of the study was therefore, to evaluate the antimicrobial activities of some selected plant extracts in the in vitro control of $A$. ochraceus and in vivo control of some pathogenic organisms causing rot of yam tubers in storage and recommend the use of these plant extracts to farmers.

\section{Materials and Methods}

\section{Sample Collection of Diseased Yam Tubers}

Decayed yam tubers (D. rotundata) with varying degrees of rots showing different kinds of symptoms from Tor-Donga, Benue State, Nigeria were collected from different farmers' barns. The collected tubers were packaged in sterile polyethylene bags in order to prevent them from further attack by insects and pathogens and were thereafter taken to the Advanced Plant Pathology Laboratory, Federal University of Agriculture, Makurdi, Nigeria for isolation and identification. In the laboratory, the samples were protected from rodent attack using wire mesh. The medium used for growing fungal organisms was Potato Dextrose Agar (PDA) which was prepared according to manufacturer's recommendation.

\section{Isolation of Aspergillus Ochraceus}

Infected yam tubers showing various degrees of rot symptoms were washed in running tape water before cutting at interphase between rotted and healthy tissues. Cut tissues were surface sterilized in 5\% Sodium hypochlorite (commercial bleach) solution for approximately 2 minutes. Tissues were thereafter removed and rinsed in four successive changes of sterile distilled water. The pieces were then placed on sterile what man No.42 filter paper (Sigma-Aldrich) in the laminar Air flow cabinet to dry for 2 minutes before inoculation.

\section{Identification of $A$. ochraceus}

Dried infected tissues were later picked from the sterile filter paper using sterile forceps and were aseptically platted in sterilized Petri plates containing solidified freshly prepared potato dextrose agar (PDA) medium. The plates were incubated at ambient room temperature $\left(30 \pm 5^{\circ} \mathrm{C}\right)$ for five days to allow for adequate growth of fungal mycelial. Different fungal colonies were seen on the plates, from which $A$. ochraceus was identified, purified and multiplied on PDA. Identification was on the basis of growth using cultural, morphological 


\section{Open Access Journal of Microbiology \& Biotechnology}

and microscopic characteristics and the characteristics were compared with existing authorities $[27,28]$.

\section{Pathogenicity Test of $A$. ochraceus}

The method of Gwa and Nwankiti [10] were adopted for pathogenicity test of $A$. ochraceus. Healthy yam tubers were obtained from same location where rotted yam were collected, they were washed in running tap water, sterilized with 5\% Sodium hypochlorite solution for 30 seconds and rinsed in four successive changes of sterile distilled water. A sterile $5 \mathrm{~mm}$ cork borer (sterilized by flaming) was punched into the healthy looking yam tubers to a depth of $4 \mathrm{~mm}$ and the bored tissues were removed. A $5 \mathrm{~mm}$ diameter disc from the pure culture of $A$. ochraceus was cut and replaced in the holes created. Same procedure was used for the control experiment except that sterile agar discs were used instead of the inoculum obtained from A. ochraceus in the holes created in the tubers [22]. The remaining parts of the holes were completely sealed with Petroleum jelly to prevent contamination by other pathogenic organisms. Treatments with $A$. ochraceus tubers were replicated three times and the yam tubers were incubated at ambient room temperature $\left(30 \pm 5^{\circ} \mathrm{C}\right)$ under sterile condition for 14 days for growth to establish. When growths were fully established, the inoculated yam tubers were cut transversely at point of inoculation to determine the extent of infection and disease development. Disease symptoms that developed on the artificially inoculated yam tubers with A. ochraceus after the incubation period were compared with those naturally infected tubers initially collected from farmers' barns. Re-isolation of $A$. ochraceus from the inoculated diseased yam tubers were done and cultured on PDA plates. The characteristic culture of the tested fungus obtained was compared with the culture initially collected from the naturally infected tubers.

\section{Preparation of Plant Extracts}

The methods of Gwa and akombo and Gwa, et al. [9,22] were used. Seeds of Piper guineense (Black Pepper), Rhizomes of Zingiber officinale (Ginger), leaves of Azadirachta indica (Neem), leaves of Carica papaya (Pawpaw) and leaves of Nicotiana tabacum (Tobacco) were washed thoroughly with cold running tap water, airdried and separately ground into fine powder using pestle and mortar. Measurement of $30 \mathrm{~g}, 60 \mathrm{~g}$ and $90 \mathrm{~g}$ of the powder of each plant extracts was added to 1litre of sterile hot $\left(100^{\circ} \mathrm{C}\right)$ distilled water separately in $1500 \mathrm{Ml}$ Pyrex flask. The mixtures were left for 24 hours before filtration using four-fold sterile cheese cloth to give concentrations of $30 \mathrm{~g} / \mathrm{L}, 60 \mathrm{~g} / \mathrm{L}$ and $90 \mathrm{~g} / \mathrm{L}$, respectively. The filtrates obtained were used as plant extracts in the experiment. The synthetic chemical; mancozeb, was prepared by dissolving $4 \mathrm{~g}, 8 \mathrm{~g}$ and $12 \mathrm{~g}$ separately in one litre of cold sterile distilled water to obtain concentrations of $4 \mathrm{~g} / \mathrm{L}, 8 \mathrm{~g} / \mathrm{L}$ and $12 \mathrm{~g} / \mathrm{L}$, respectively. The potencies of the plant extracts as well as the synthetic fungicide were compared for their in vitro fungicidal activity in reducing mycelial growth of $A$. ochraceus and in vivo control of yam pathogens in storage.

\section{In vitro Antifungal Activity of Plant Extracts on the Mycelial Growth of A. ochraceus}

The antifungal in vitro assays were carried out following the method described by Amadioha and Obi, [29]. It involves creating four equal sections on each plate by drawing two perpendicular lines at the bottom of the plate. The intersection of the two lines indicates the centre of the plates. This was done before dispensing PDA into each of the plates. The prepared medium was poured into sterilized Petri dishes and $5 \mathrm{ml}$ of each plant extracts and chemical fungicide at their respective concentrations were poured into Petri dishes containing $15 \mathrm{ml}$ of the medium separately [30] mixed well and allowed to solidify. The solidified medium was inoculated centrally at the point of intersection of the two perpendicular lines drawn at the bottom of the plate with $5 \mathrm{~mm}$ diameter discs which was obtained from one-week-old cultures of A. ochraceus grown on PDA plates as inoculum [10,31]. The treatments were replicated three times for each of the concentrations. The procedure was the same in the control experiments except that $5 \mathrm{ml}$ of sterile distilled water was added to PDA instead of plant extracts. The treatments and control experiments were completely randomized [32] and incubated at ambient room temperature $\left(30 \pm 5^{\circ} \mathrm{C}\right)$ for 120 hours. Measurement of mycelial radial growth was done and fungitoxicity was calculated as percentage growth inhibition of $A$. ochraceus using the formula described by Korsten and De Jager.

Where,

$$
P G I(\%)=\frac{R-R_{1}}{R} \times 100
$$

PGI $=$ Percentage Growth Inhibition

$\mathrm{R}=$ the distance (measured in $\mathrm{mm}$ ) from the point of inoculation to the colony margin in control plate,

$\mathrm{R}_{1}=$ the distance of fungal growth from the point of inoculation to the colony margin in treated plate.

The efficacies of the aqueous plant extracts and the synthetic fungicide that were found to be effective against 


\section{Open Access Journal of Microbiology \& Biotechnology}

A. ochraceus in vitro were used to control pathogens of yam tubers in storage for five months.

\section{Effectiveness of Some Plant Extracts and Chemical Fungicide in Controlling Yam Tuber Rot Pathogens in Storage}

The efficacy of three plants extracts namely: seeds of P. guineense, rhizomes of $Z$. officinale and leaves of $A$. indica and chemical fungicide (mancozeb) that were found to posses' more fungicidal properties in vitro were tested for efficacy in controlling yam tuber rot pathogens in vivo at different level of concentrations. Plant extracts were prepared as described above and Ogoja cultivar of white yam tubers were each sprayed with three plant extracts at concentrations of $30 \mathrm{~g} / \mathrm{L}, 60 \mathrm{~g} / \mathrm{L}$ and $90 \mathrm{~g} / \mathrm{L}$, respectively using a hand sprayer. The synthetic chemical, mancozeb was applied at a concentration of $4 \mathrm{~g} / \mathrm{L}$ respectively since there were no differences in culture in percentage growth inhibition of $A$. ochraceus using $8 \mathrm{~g} / \mathrm{L}$ and $12 \mathrm{~g} / \mathrm{L}$. After spraying, the tubers were allowed to dry after which tubers were stored for five months. Three tubers formed a treatment; this was replicated three times bringing the total to 9 tubers per treatment. There were 11 treatments (three plant extracts at three concentrations each, mancozeb and control). A total of 99 tubers of Ogoja yam were used for the experiment. The treatments were completely randomized and control was set up for each cultivar in which sterile distilled water was sprayed on the yam tubers and allowed to dry (no plant extract or chemical applied). Data on the potency of the extracts and chemical fungicide in controlling rot causing pathogens during storage were collected at monthly interval for five months. The numbers of unrotten and rotten tubers in each treatment were recorded. The effectiveness of the concentrations of plant extracts and chemical fungicide in controlling yam tuber rot pathogens in storage were evaluated. The Decay Reduction Index [33] defined below, was calculated as a measure of the effectiveness of each plant extract and chemical fungicide in controlling yam tuber rot pathogens in storage at different concentrations after final data collection as:

$$
=\frac{\begin{array}{c}
\text { Decay Reduction Index }(D R I) \\
\% \text { decay in control }-\% \text { decay in treated tubers }
\end{array}}{\% \text { decay in control }}
$$

\section{Statistical Analysis}

Analysis of variance (ANOVA) using Genstat Discovery Edition 12 for ANOVA and means separation and Graph Pad Prism 6 for trend graphs were used. Statistical F-tests were evaluated at $P \leq 0.05$ using Fisher's least significant differences (FLSD) [34].

\section{Results}

Fungal organisms identified in Tor-Donga were Fusarium moniliforme, F. oxysporum Botryodiplodia theobromae, Aspergillus flavus, A. niger, A. ochraceus, Penicillium purpurogenum and Pestalotia sp. Cultural and morphological characteristics of A. ochraceus on PDA shows rapid and fast growth. There was powdery brown colour almost covering the plate within 7 days of incubation (Figure 1: Plate 1). Microscopic examination shows that each conidiophore ended in a terminal enlarged spherical swellings (Figure 1: Plate 2).
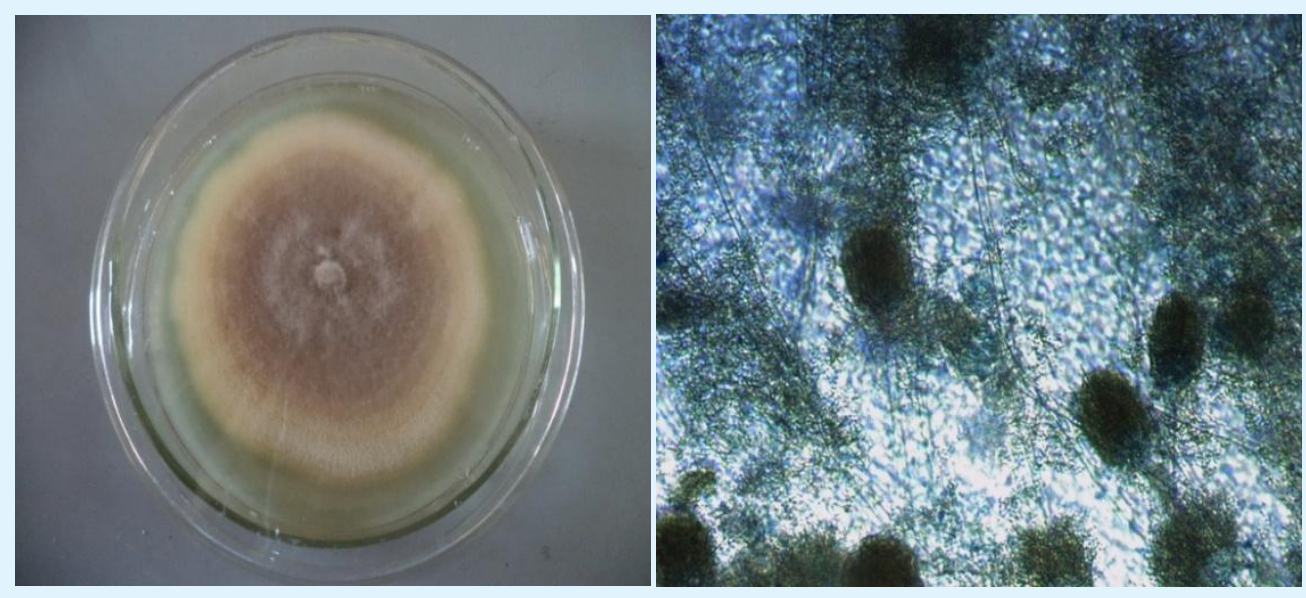

Figure 1: Plate 1: Culture of Aspergillus ochraceus. Plate 2: Photomicrograph of A. ochraceus on Potato Dextrose Agar $(\times 10)$ showing Conidia and Conidiophore $(\times 10)$. 


\section{Open Access Journal of Microbiology \& Biotechnology}

\section{Pathogenicity Test}

Result of pathogenicity test conducted on Pepa white yam using the inoculum collected from $A$. ochraceus shows that the pathogen was able to induce rot in the healthy looking yam tubers 14 days after inoculation (Figure 2: Plate 3). Healthy Pepa yam tubers that were not inoculated with the test fungus showed no symptoms of rot in the bored yam tubers (Figure 2: Plate 4).

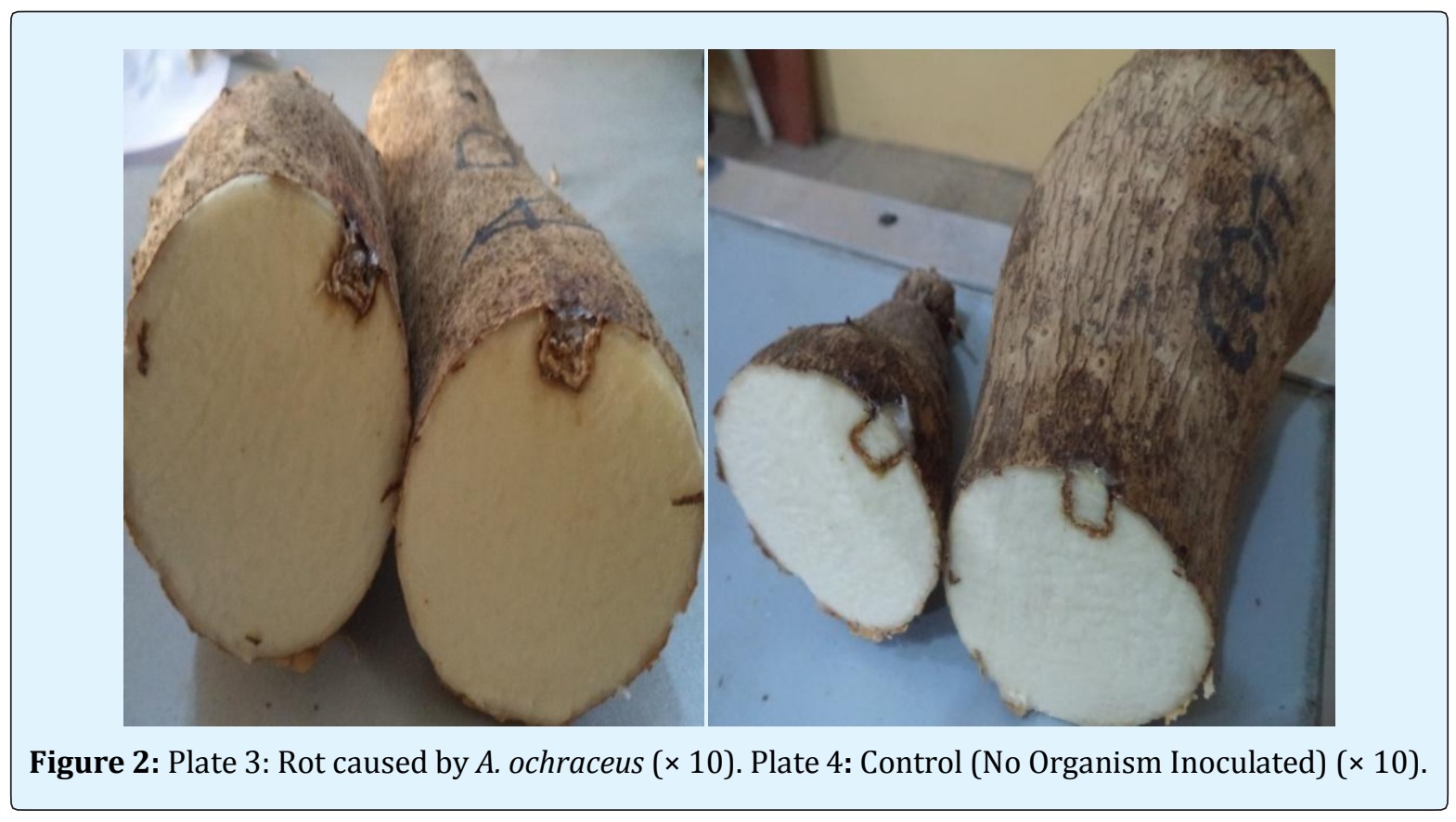

\section{In vitro Fungitoxic Effect of Plant Extracts and Fungicide on the Mycelial Growth Inhibition of A. ochraceus}

Table 1 shows that P. guineense, Z. officinale, A. indica, C. papaya and $N$. tabacum extracts possess fungicidal properties at different concentration levels against $A$. ochraceus in vitro. However, only mancozeb gave $100 \%$ inhibition of mycelial growth of $A$. ochraceus indicating that only the synthetic fungicide completely inhibited the growth of the pathogen. All the plant extracts were able to reduce growth of the test fungus throughout the period of incubation irrespective of the level of concentration used and duration of incubation. Though the potency of the extracts decreased with increase in the period of incubation; the test fungus was effectively controlled throughout the test period. P. guineense and Z. officinale were considered better extracts than A. indica, C. papaya and $N$. tabacum at all the level of concentrations after 72 hours. There were no significant differences $(P \leq 0.05)$ throughout the period of incubation at concentration I (30 $\mathrm{g} / \mathrm{L})$ of all the plant extracts. At concentration II ( $60 \mathrm{~g} / \mathrm{L})$, only Z. officinale and N. tabacum were not significantly different $(P \leq 0.05)$ across duration of incubation while all the plant extracts significantly inhibited the mycelial growth of $A$. ochraceus at concentration III $(90 \mathrm{~g} / \mathrm{L})$ respectively. The results further revealed that there were significant differences $(P \leq 0.05)$ among plant extracts for each of the concentration levels tested throughout the period of incubation (Table 2). Mean percentage growth inhibition of A. ochraceus after 120 hours of incubation showed that $P$. guineense and $Z$. officinale were more effective at each level of concentration; this was closely followed by $A$. indica at concentration I and II while $N$. tabacum was third in activity at concentration III (Table 2). Mean percentage growth inhibition of A. ochraceus after 120 hours of incubation showed significant differences $(P \leq 0.05)$ among plant extracts for each concentration (Table 2). Mean percentage growth inhibition of three concentrations $(30 \mathrm{~g} / \mathrm{L}, 60 \mathrm{~g} / \mathrm{L}$ and $90 \mathrm{~g} / \mathrm{L}$ ) of each plant extracts on A. ochraceus throughout the period of incubation revealed that the plant extracts were more effective at the beginning initial period of incubation compared with the later periods (Figure 3). 


\begin{tabular}{|c|c|c|c|c|c|c|c|}
\hline \multirow{2}{*}{ Plant Extract } & \multirow{2}{*}{\begin{tabular}{|c|} 
Concentration \\
$(\mathrm{g} / \mathrm{L})$
\end{tabular}} & \multicolumn{5}{|c|}{ Period of Incubation (Hours) and Percentage Growth Inhibition (\%) } & \multirow{2}{*}{ Mean } \\
\hline & & 24 & 48 & 72 & 96 & 120 & \\
\hline \multirow{3}{*}{ Piper guineense } & 30 & $44.44 \pm 5.56$ & $51.52 \pm 2.69$ & $56.46 \pm 2.07$ & $52.47 \pm 1.24$ & $54.76 \pm 2.38$ & $51.93 \pm 1.62$ \\
\hline & 60 & $100.00 \pm 0.00^{\mathrm{a}}$ & $66.90 \pm 6.56^{\mathrm{b}}$ & $65.60 \pm 6.49 \mathrm{~b}$ & $58.70 \pm 2.44 \mathrm{~b}$ & $61.61 \pm 2.80^{\mathrm{b}}$ & $70.56 \pm 4.35$ \\
\hline & 90 & $100.00 \pm 0.00^{\mathrm{a}}$ & $69.93 \pm 3.85^{\mathrm{b}}$ & $69.10 \pm 3.00^{b}$ & $66.21 \pm 2.37 \mathrm{~b}$ & $65.51 \pm 3.07 \mathrm{~b}$ & $74.15 \pm 3.64$ \\
\hline \multirow{3}{*}{ Zingiber officinale } & 30 & $38.90 \pm 20.00$ & $48.48 \pm 2.69$ & $54.70 \pm 2.20$ & $57.42 \pm 1.99$ & $56.76 \pm 1.99$ & $51.25 \pm 3.93$ \\
\hline & 60 & $83.30 \pm 16.70$ & $64.34 \pm 4.90$ & $59.63 \pm 1.19$ & $59.98 \pm 1.17$ & $60.65 \pm 2.20$ & $65.59 \pm 3.83$ \\
\hline & 90 & $100.00 \pm 0.00^{\mathrm{a}}$ & $67.37 \pm 4.82^{\mathrm{b}}$ & $64.25 \pm 3.21^{b}$ & $66.12 \pm 2.88^{\mathrm{b}}$ & $64.55 \pm 2.72^{\mathrm{b}}$ & $72.46 \pm 3.88$ \\
\hline \multirow{3}{*}{ Azadiracta indica } & 30 & $50.00 \pm 28.90$ & $42.42 \pm 7.89$ & $51.91 \pm 4.94$ & $46.15 \pm 2.22$ & $44.97 \pm 2.32$ & 46.9 \\
\hline & 60 & $88.90 \pm 11.10^{\mathrm{a}}$ & $56.18 \pm 6.96^{b}$ & $53.18 \pm 0.68 \mathrm{~b}$ & $49.91 \pm 2.14^{b}$ & $51.82 \pm 2.47 \mathrm{~b}$ & $60.00 \pm 4.52$ \\
\hline & 90 & $100.00 \pm 0.00^{\mathrm{a}}$ & $56.18 \pm 5.36^{b}$ & $57.88 \pm 2.75 \mathrm{~b}$ & $57.51 \pm 2.23^{b}$ & $59.52 \pm 4.83^{\mathrm{b}}$ & 66.22 \\
\hline \multirow{3}{*}{ Carica papaya } & 30 & $38.90 \pm 20.00$ & $40.33 \pm 6.95$ & $49.53 \pm 7.06$ & $43.59 \pm 3.39$ & $34.23 \pm 2.89$ & $41.31 \pm 4.09$ \\
\hline & 60 & $83.30 \pm 16.70^{a}$ & $56.18 \pm 5.36^{b}$ & $57.80 \pm 3.19$ a & $51.01 \pm 6.34 \mathrm{~b}$ & $43.84 \pm 5.01^{b}$ & $58.43 \pm 4.83$ \\
\hline & 90 & $100.00 \pm 0.00^{\mathrm{a}}$ & $58.74 \pm 7.00^{\mathrm{b}}$ & $62.49 \pm 4.9^{b}$ & $61.08 \pm 4.05^{b}$ & $59.52 \pm 4.83^{b}$ & $68.37 \pm 4.61$ \\
\hline \multirow{3}{*}{$\begin{array}{l}\text { Nicotiana } \\
\text { tabacum }\end{array}$} & 30 & $27.80 \pm 14.70$ & $40.79 \pm 5.02$ & $43.64 \pm 2.83$ & $48.63 \pm 3.32$ & $40.12 \pm 2.80$ & $40.19 \pm 3.32$ \\
\hline & 60 & $66.70 \pm 16.70$ & $56.18 \pm 5.36$ & $59.63 \pm 1.19$ & $55.04 \pm 1.33$ & $49.82 \pm 3.15$ & $57.47 \pm 3.37$ \\
\hline & 90 & $100.00 \pm 0.00^{\mathrm{a}}$ & $62.23 \pm 0.69 \mathrm{~b}$ & $64.49 \pm 1.10^{b}$ & $61.26 \pm 0.27 \mathrm{~b}$ & $62.56 \pm 3.15^{b}$ & $70.11 \pm 4.05$ \\
\hline \multirow{3}{*}{ Mancozeb $^{\circledR}$} & 4 & $100.00 \pm 0.00$ & $100.00 \pm 0.00$ & $100.00 \pm 0.00$ & $100.00 \pm 0.00$ & $100.00 \pm 0.00$ & $100.00 \pm 0.00$ \\
\hline & 8 & $100.00 \pm 0.00$ & $100.00 \pm 0.00$ & $100.00 \pm 0.00$ & $100.00 \pm 0.00$ & $100.00 \pm 0.00$ & $100.00 \pm 0.00$ \\
\hline & 12 & $100.00 \pm 0.00$ & $100.00 \pm 0.00$ & $100.00 \pm 0.00$ & $100.00 \pm 0.00$ & $100.00 \pm 0.00$ & $100.00 \pm 0.00$ \\
\hline
\end{tabular}

Table 1: Percentage Growth Inhibition of A. ochraceus by different Concentrations of Plant Extracts and Chemical Fungicide after different Incubation Period.

Means on the same row (for each Plant Extract) with the different superscript are statistically significant

$(\mathrm{P} \leq 0.05)$ by period of incubation

\begin{tabular}{|c|c|c|c|c|c|c|}
\hline \multicolumn{7}{|c|}{ Period of Incubation (Hours) and Percentage Growth Inhibition (\%) } \\
\hline Plant Extract & 24 & 48 & 72 & 96 & 120 & Mean \\
\hline \multicolumn{7}{|l|}{ I } \\
\hline Azadiracta indica & $50.00 \pm 28.90^{\mathrm{ab}}$ & $42.42 \pm 7.89^{\mathrm{b}}$ & $51.19 \pm 4.94 \mathrm{bc}$ & $46.15 \pm 2.22^{\mathrm{cd}}$ & $44.97 \pm 2.32^{c}$ & $46.95 \pm 5.23^{\mathrm{bc}}$ \\
\hline Carica papaya & $38.90 \pm 20.00^{\mathrm{b}}$ & $40.33 \pm 6.95^{\mathrm{b}}$ & $49.53 \pm 7.06^{\mathrm{bc}}$ & $43.59 \pm 3.39^{\mathrm{d}}$ & $34.23 \pm 2.89^{\mathrm{d}}$ & $41.31 \pm 4.09^{c}$ \\
\hline Nicotiana tabacum & $27.80 \pm 14.70^{\mathrm{b}}$ & $40.79 \pm 5.02^{\mathrm{b}}$ & $43.64 \pm 2.83^{\mathrm{c}}$ & $48.63 \pm 3.32^{\mathrm{cd}}$ & $40.12 \pm 2.80^{\mathrm{cd}}$ & $\pm 3.32^{\mathrm{c}}$ \\
\hline Piper guineense & $44.44 \pm 5.56^{\mathrm{b}}$ & $51.52 \pm 2.69^{\mathrm{b}}$ & $56.46 \pm 2.07^{\mathrm{b}}$ & $52.47 \pm 1.24^{\mathrm{bc}}$ & $54.76 \pm 2.38^{\mathrm{b}}$ & $\pm 1.62^{\mathrm{b}}$ \\
\hline Zingiber officinale & $38.90 \pm 20.00^{\mathrm{b}}$ & $48.48 \pm 2.69^{b}$ & $54.70 \pm 2.20^{\mathrm{bc}}$ & $57.42 \pm 1.99^{b}$ & $56.76 \pm 1.99 \mathrm{~b}$ & $51.25 \pm 3.93^{b}$ \\
\hline Mancozeb & $100.00 \pm 0.00^{\mathrm{a}}$ & $100.00 \pm 0.00^{\mathrm{a}}$ & $100.00 \pm 0.00^{\mathrm{a}}$ & $100.00 \pm 0.00^{\mathrm{a}}$ & $100.00 \pm 0.00^{\mathrm{a}}$ & $100.00 \pm 0.00^{\mathrm{a}}$ \\
\hline$L S D$ & 54.58 & 15.42 & 12.02 & 7.22 & 7.02 & 9.82 \\
\hline \multicolumn{7}{|l|}{ II } \\
\hline Azadiracta indica & $88.90 \pm 11.10^{\mathrm{ns}}$ & $56.18 \pm 6.96^{b}$ & $53.18 \pm 0.68^{c}$ & $49.91 \pm 2.14^{\mathrm{d}}$ & $51.82 \pm 2.47 \mathrm{~cd}$ & $60.00 \pm 4.52^{\mathrm{bc}}$ \\
\hline Carica papaya & $83.30 \pm 16.70 \mathrm{~ns}$ & $56.18 \pm 5.36^{b}$ & $57.80 \pm 3.19 \mathrm{bc}$ & $51.01 \pm 5.24^{\mathrm{cd}}$ & $43.84 \pm 5.01^{d}$ & $58.43 \pm 4.83^{c}$ \\
\hline Nicotiana tabacum & $66.70 \pm 16.70^{\mathrm{ns}}$ & $56.18 \pm 5.36^{b}$ & $59.63 \pm 1.19 \mathrm{bc}$ & $55.04 \pm 1.33^{\mathrm{bcd}}$ & $49.82 \pm 3.15^{\mathrm{d}}$ & $57.47 \pm 3.37 \mathrm{c}$ \\
\hline Piper guineense & $100.00 \pm 0.00^{\mathrm{ns}}$ & $66.90 \pm 6.56^{b}$ & $65.60 \pm 6.49 \mathrm{~b}$ & $58.70 \pm 2.44 \mathrm{bc}$ & $61.61 \pm 2.80^{\mathrm{b}}$ & $70.56 \pm 4.35^{b}$ \\
\hline Zingiber officinale & $83.30 \pm 16.70^{\mathrm{ns}}$ & $64.34 \pm 4.90^{\mathrm{b}}$ & $59.63 \pm 1.19 \mathrm{bc}$ & $59.98 \pm 1.17 \mathrm{~b}$ & $60.65 \pm 2.20 \mathrm{bc}$ & $65.59 \pm 3.83^{\mathrm{bc}}$ \\
\hline Mancozeb & $100.00 \pm 0.00^{\mathrm{ns}}$ & $100.00 \pm 0.00^{\mathrm{a}}$ & $100.00 \pm 0.00^{\mathrm{a}}$ & $100.00 \pm 0.00^{\mathrm{a}}$ & $100.00 \pm 0.00^{\mathrm{a}}$ & $100.00 \pm 0.00^{\mathrm{a}}$ \\
\hline$L S D$ & $38.91^{n s}$ & 16.55 & 9.38 & 8.17 & 9.23 & 10.81 \\
\hline \multicolumn{7}{|l|}{ III } \\
\hline Azadiracta indica & $100.00 \pm 0.00^{\mathrm{ns}}$ & $56.18 \pm 5.36^{c}$ & $57.88 \pm 2.75^{c}$ & $57.51 \pm 2.23^{c}$ & $59.52 \pm 4.83^{\mathrm{b}}$ & $66.22 \pm 4.72^{\mathrm{b}}$ \\
\hline Carica papaya & $100.00 \pm 0.00^{\mathrm{ns}}$ & $58.74 \pm 7.00 \mathrm{bc}$ & $62.49 \pm 4.95^{\text {bc }}$ & $61.08 \pm 4.05^{\mathrm{bc}}$ & $59.52 \pm 4.83^{\mathrm{b}}$ & $68.37 \pm 4.61^{b}$ \\
\hline
\end{tabular}




\section{Open Access Journal of Microbiology \& Biotechnology}

\begin{tabular}{|c|c|c|c|c|c|c|}
\hline Nicotiana tabacum & $100.00 \pm 0.00^{\mathrm{ns}}$ & $62.23 \pm 0.69^{\mathrm{bc}}$ & $64.49 \pm 1.10^{\mathrm{bc}}$ & $61.26 \pm 0.27^{\mathrm{bc}}$ & $62.56 \pm 3.15^{\mathrm{b}}$ & $70.11 \pm 4.05^{\mathrm{b}}$ \\
\hline Piper guineense & $100.00 \pm 0.00^{\mathrm{ns}}$ & $69.93 \pm 3.85^{\mathrm{b}}$ & $69.10 \pm 3.00^{\mathrm{b}}$ & $66.21 \pm 2.37^{\mathrm{b}}$ & $65.51 \pm 3.07^{\mathrm{b}}$ & $74.15 \pm 3.64^{\mathrm{b}}$ \\
\hline Zingiber officinale & $100.00 \pm 0.00^{\mathrm{ns}}$ & $67.37 \pm 4.82^{\mathrm{bc}}$ & $64.25 \pm 3.21^{\mathrm{bc}}$ & $66.12 \pm 2.88^{\mathrm{b}}$ & $64.55 \pm 2.72^{\mathrm{b}}$ & $72.46 \pm 3.88^{\mathrm{b}}$ \\
\hline Mancozeb & $100.00 \pm 0.00^{\mathrm{ns}}$ & $100.00 \pm 0.00^{\mathrm{a}}$ & $100.00 \pm 0.00^{\mathrm{a}}$ & $100.00 \pm 0.00^{\mathrm{a}}$ & $100.00 \pm 0.00^{\mathrm{a}}$ & $100.00 \pm 0.00^{\mathrm{a}}$ \\
\hline$L S D$ & - & 13.57 & 9.12 & 7.47 & 10.78 & 10.78 \\
\hline
\end{tabular}

Table 2: Mean Percentage Growth Inhibition of A. ochraceus at different Concentrations of Plant Extracts and Chemical Fungicide after 120 hours of Incubation in vitro.

Means on the same column (for each concentration) with different superscript are statistically significant $(\mathrm{P} \leq 0.05)$. (Conc $\mathrm{I}=30 \mathrm{~g} / \mathrm{L}$ of Plant extract, $4 \mathrm{~g} / \mathrm{L}$ of

Mancozeb; Conc II = $60 \mathrm{~g} / \mathrm{L}$ of Plant extract, $8 \mathrm{~g} / \mathrm{L}$ of Mancozeb; Conc III = $90 \mathrm{~g} / \mathrm{L}$ of Plant extract, $12 \mathrm{~g} / \mathrm{L}$ of Mancozeb)

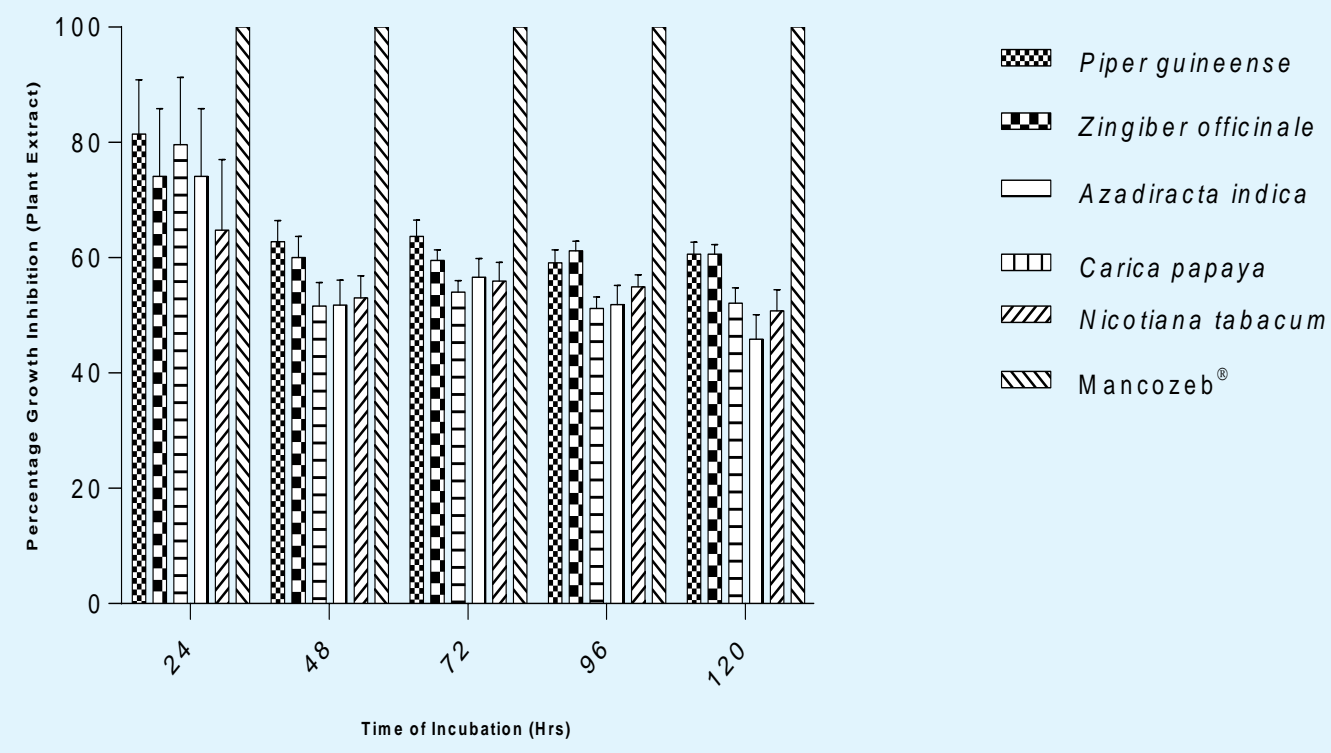

Figure 3: Mean percentage growth inhibition of three concentrations of plant extracts $(30 \mathrm{~g} / \mathrm{L}, 60 \mathrm{~g} / \mathrm{L}$ and $90 \mathrm{~g} / \mathrm{L})$ and mancozeb (4 g/L, $8 \mathrm{~g} / \mathrm{L}$ and $12 \mathrm{~g} / \mathrm{L}$ ) on growth of $A$. ochraceus.

\section{Effect of different concentrations of plant extracts and chemical fungicide in controlling tuber rot of Pepa after five months of storage}

Figure 4 shows the effect of different concentrations of plants extracts in controlling rot of Pepa yam tubers after five months of storage. Results revealed that the concentration of $30 \mathrm{~g} / \mathrm{L}$ of P. guineense on Pepa tuber gave the highest decay reduction index in December, 2015 and February, 2016 with the value of 1each and lowest in March, 2016 and April, 2016 with the value of 0.44 each. Concentration II $(60 \mathrm{~g} / \mathrm{L})$ recorded the highest value of 1 in December, 2015 and January, 2016 each and the lowest value of 0.66 each for the months of February, March and April, 2016. The performance of the extract at concentration III $(90 \mathrm{~g} / \mathrm{L})$ was the same throughout the storage period with the decay reduction index value of 1 for each month. The efficacy of $Z$. officinale at $30 \mathrm{~g} / \mathrm{L}$ was highest in December, 2015 with the value of 0.66 and lowest in January and February, 2016 with the value of 0.33 for each month. Extract of Z. officinale was most effective at $60 \mathrm{~g} / \mathrm{L}$ and $90 \mathrm{~g} / \mathrm{L}$ with the value of 1 throughout the storage period. The effectiveness of $A$. indica at $30 \mathrm{~g} / \mathrm{L}$ was similar to $60 \mathrm{~g} / \mathrm{L}$ with the highest value of 1 in December, January and February each and least in April with the value of 0.66 . At $90 \mathrm{~g} / \mathrm{L}$ the 
performance rose to the peak of 1 throughout the duration of storage. The synthetic chemical Mancozeb gave an even performance of 1 throughout the period of storage (Figure 4).

\section{Effects of Mean Concentrations of Plant Extract and Chemical Fungicide in Controlling Tuber Rot of Pepa After Five Months of Storage}

Table 3 shows the results of the efficacy of mean concentrations of plant extracts $(30 \mathrm{~g} / \mathrm{L}, 60 \mathrm{~g} / \mathrm{L}$ and 90 $\mathrm{g} / \mathrm{L})$ and chemical fungicide $(4 \mathrm{~g} / \mathrm{L})$ in controlling rot of Pepa yam tuber in storage. Results showed that mean decay reduction index in December, 2015 was 1.00 for each of Mancozeb, $A$. indica and $P$. guineense while $Z$. officinale recorded the value of 0.88 . In January and February, 2016, Mancozeb and A. indica recorded the mean value of 1.00 each while $P$. guineense and $Z$. officinale recorded mean value of 0.88 and 0.77 , respectively. Results of March and April were the same for Mancozeb (1.00), P. guineense $(0.70)$ and $Z$. officinale (0.85) while extract from $A$. indica recorded the mean value of 0.88 and 0.77 for March and April, respectively. Mean decay reduction index of plant extracts and chemical fungicide after five months of storage of Pepa showed that Mancozeb (1.00) was more effective followed by $A$. indica (0.93) while $P$. guineense and $Z$. officinale recorded similar efficacy of 0.83 each in controlling pathogens of Pepa yam tubers. There was no significant difference $(\mathrm{P} \leq 0.05)$ in potency among the plant extracts for each month of storage of Pepa yam tubers. Mean decay reduction index also showed no significant difference $(\mathrm{P} \leq 0.05)$ among treatments (Table 3$)$.

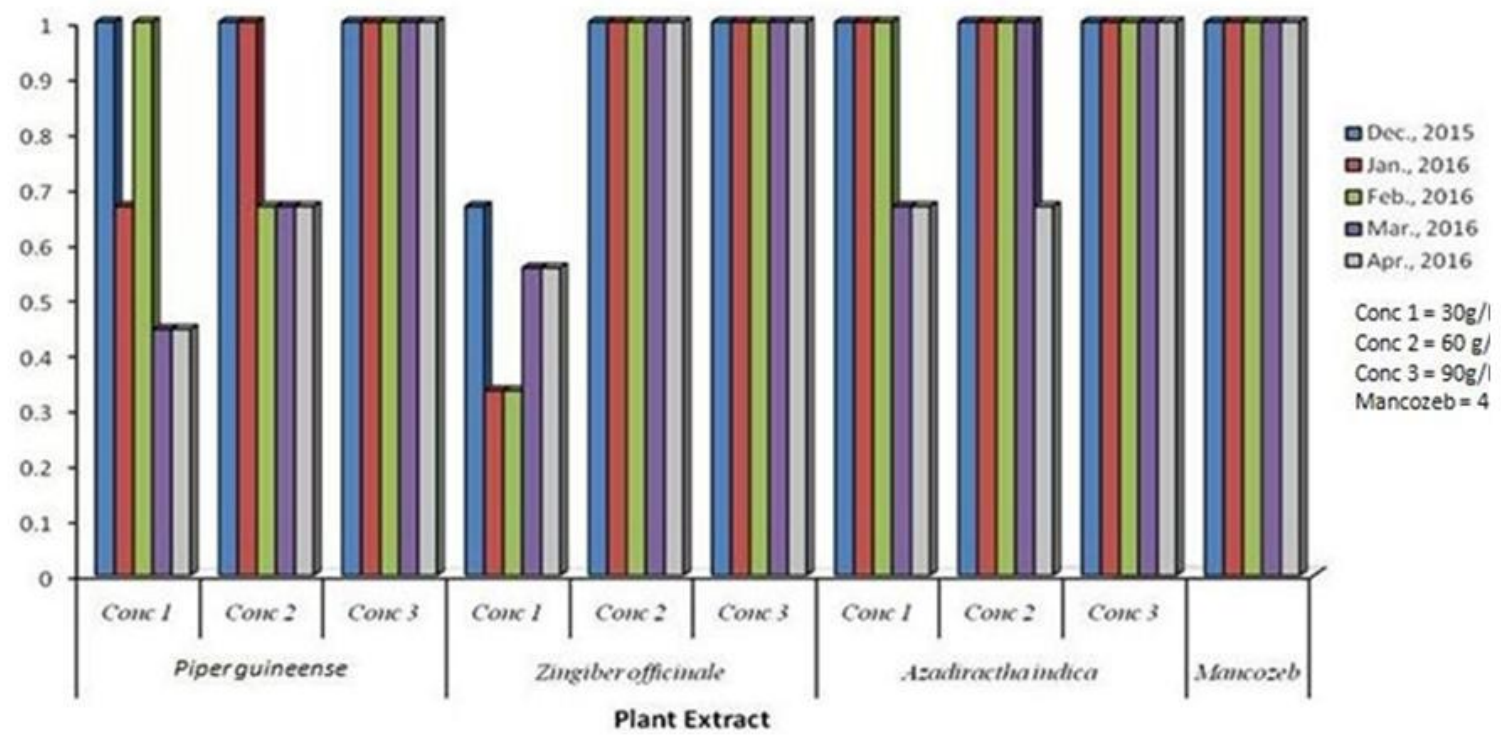

Figure 4: Decay reduction index of plant extracts and chemical fungicide at different concentrations after five months of storage of Pepa tuber.

\begin{tabular}{|c|c|c|c|c|c|}
\hline \multirow{2}{*}{ Period of Storage } & \multicolumn{4}{|c|}{ Plant Extract } & \multirow{2}{*}{$L S D$} \\
\hline & Mancozeb® & A. indica & P.guineense & Z. officianale & \\
\hline \multicolumn{6}{|c|}{ It Year } \\
\hline Dec., 2015 & $1.00 \pm 0.00$ & $1.00 \pm 0.00$ & $1.00 \pm 0.00$ & $0.88 \pm 0.11$ & $0.21^{n s}$ \\
\hline Jan., 2016 & $1.00 \pm 0.00$ & $1.00 \pm 0.00$ & $0.88 \pm 0.11$ & $0.78 \pm 0.14$ & $0.35^{n s}$ \\
\hline Feb., 2016 & $1.00 \pm 0.00$ & $1.00 \pm 0.00$ & $0.88 \pm 0.11$ & $0.77 \pm 0.14$ & $0.35^{n s}$ \\
\hline Mar., 2016 & $1.00 \pm 0.00$ & $0.88 \pm 0.11$ & $0.70 \pm 0.15$ & $0.85 \pm 0.11$ & $0.42^{n s}$ \\
\hline Apr., 2016 & $1.00 \pm 0.00$ & $0.77 \pm 0.14$ & $0.70 \pm 0.15$ & $0.85 \pm 0.15$ & $0.46^{n s}$ \\
\hline Mean (1 ${ }^{\text {st }}$ Year) & $1.00 \pm 0.00$ & $0.93 \pm 0.04$ & $0.83 \pm 0.08$ & $0.83 \pm 0.11$ & $0.29^{n s}$ \\
\hline
\end{tabular}




\section{Open Access Journal of Microbiology \& Biotechnology}

\begin{tabular}{|c|c|c|c|c|c|}
\hline \multicolumn{7}{|c|}{ 2 $^{\text {nd }}$ Year } \\
\hline Dec., 2016 & $0.66 \pm 0.33$ & $0.66 \pm 0.16$ & $0.66 \pm 0.16$ & $0.55 \pm 0.17$ & $0.60^{\text {ns }}$ \\
\hline Jan., 2017 & $0.66 \pm 0.33$ & $0.66 \pm 0.16$ & $0.66 \pm 0.16$ & $0.33 \pm 0.16$ & $0.59^{n s}$ \\
\hline Feb., 2017 & $0.66 \pm 0.33$ & $0.55 \pm 0.17$ & $0.44 \pm 0.17$ & $0.22 \pm 0.14$ & $0.59^{n s}$ \\
\hline Mar., 2017 & $1.00 \pm 0.00$ & $0.77 \pm 0.14$ & $0.77 \pm 0.14$ & $0.55 \pm 0.17$ & $0.52^{n s}$ \\
\hline Apr., 2017 & $1.00 \pm 0.00$ & $0.66 \pm 0.16$ & $0.66 \pm 0.16$ & $0.55 \pm 0.17$ & $0.57^{n s}$ \\
\hline Mean (2 ${ }^{\text {nd }}$ Year) & $\mathbf{0 . 8 0 \pm 0 . 2 0}$ & $\mathbf{0 . 6 6 \pm 0 . 0 9}$ & $\mathbf{0 . 6 4} \pm \mathbf{0 . 0 9}$ & $\mathbf{0 . 4 4 \pm 0 . 1 1}$ & $\mathbf{0 . 3 6}^{\text {ns }}$ \\
\hline \multicolumn{7}{|c|}{ Dean (both Years) } \\
\hline \multicolumn{7}{|c|}{} \\
\hline $1^{\text {st }}$ Year & $1.00 \pm 0.00$ & $0.93 \pm 0.04^{\mathrm{a}}$ & $0.83 \pm 0.08$ & $0.83 \pm 0.11^{\mathrm{a}}$ & \\
\hline $2^{\text {nd }}$ Year & $0.80 \pm 0.20$ & $0.66 \pm 0.09^{\mathrm{b}}$ & $0.64 \pm 0.09$ & $0.44 \pm 0.11^{\mathrm{b}}$ & \\
\hline LSD & $0.23^{\text {ns }}$ & 0.19 & $0.26^{\text {ns }}$ & 0.31 & \\
\hline
\end{tabular}

Table 3: Decay reduction index of some plant extracts and mancozeb after two years of storage on Pepa yam tubers.

Means on the same row (comparing plant extracts) and column (comparing year of storage) with different superscript $\mathrm{a}$ and $\mathrm{b}$ are statistically significant $(\mathrm{P} \leq 0.05)$; ns $=$ not significant

\section{Discussion}

Fungi organisms such as F. moniliforme, F. oxysporum B. theobromae, A. flavus, A. niger, A. ochraceus, $P$. purpurogenum and Pestalotia sp are known to cause rot of yam tubers in storage. This confirms earlier report by Ogaraku and Usman, Ogunleye and Ayansola, Gwa, et al. Okigbo, et al. [5,8,22,35] who isolated different fungi organisms from yam tubers at various locations in Nigeria. Research conducted on Dioscorea $s p$ in Bodija, Ibaban, by Ogunleye and Ayansola [35] revealed that $A$. ochraceus and Penicillium sp. had low occurrence of $2.14 \%$ and $6.43 \%$, respectively. Inoculation of $A$. ochraceus mycelial into the healthy looking yam tubers produced rot symptoms. The pathogen entered through the holes created in the tubers and probably utilized the nutrients of the tubers as substrates for growth and development during the 14 days of incubation $[11,36]$. The tubers that were not inoculated with the test fungus however, did not show any symptom of rot indicating the absent of the rot inciting fungus in the bored yam. Extracts of P. guineense, Z. officinale A. indica, N. tabacum and $C$. papaya and the synthetic fungicide (mancozeb) all possess fungitoxic compounds that are toxic and capable of inhibiting the growth of $A$. ochraceus in vitro and controlling rot pathogens in vivo. It has been reported that plant contained secondary compounds such as alkaloids, flavonoids, terpenoids and tannins which have antimicrobial effect against a wide range of fungi $[37,38]$. The susceptibility of $A$. ochraceus to the various plant extracts varied with the duration of incubation, the type of plant extract used as well as the concentrations of the extracts which agreed with earlier report by Gwa and Akombo, Gwa and Nwankiti, Gwa and Ekefan, and Gwa, et al. $[9,10,19,22]$. Gwa and Akombo and Gwa and Nwankiti $[9,10]$ evaluated the antifungal activity of $A$. indica, $P$. guineense, Z. officinale, C. papaya and N. tabacum against A. flavus and Colletotrichum specie in vitro respectively and they reported that all the extracts significantly reduced the mycelial growth of $A$. flavus and Colletotrichum species by at least $42 \%$ at the different level of concentrations of the plant extracts tested against the pathogens.

P. guineense, $Z$. officinale were generally more fungitoxic than A. indica, C. papaya and N. tabacum in the in vitro test. This could be as a result of solubility of the active substances in water or higher concentration of the active principles in the seeds and rhizomes of $P$. guineense, Z. officinale respectively than that of $A$. indica, C. papaya and N. tabacum. This result is similar with findings of Gwa and Ekefan, Gwa, et al. [19,22]. Hycenth [39] reported the antifungal effect of $A$. indica against yam rot pathogens (Rhizopus stolonifer). Contrary to the report of Oluma and Elaigwu [40] who observed that extracts of $A$. indica had no inhibitory effect on the mycelial growth and sclerotial formation of Macrophomina phaseolina. It has been shown that $A$. indica contains phytochemical compounds such as azadirachtin, betasiterol, 6-desacetyl nimbinene and 3- desciacetyl alamine which show antifungal properties. The growth inhibition of $A$. ochraceus by $P$. guineense extracts may be probably due to the presence of phyto-chemical compounds such as piperine which increases as the concentration of $P$. guineense increased against $A$. ochraceus. Ijato [41] studied the antifungal effects of Allium sativum (rhizome) and Nicotiana tobacum (leaf) extracts on rot causing organisms on yam against Aspergillus niger, Fusarium oxysporum, Rhizopus stolonifer, Botryodiplodia 
theobromae, Aspergillus flavus and Fusarium solani and found out that both the aqueous and the ethanolic extract of the tested plants were effective as bio-killer on yam rot organisms. According to Suresh, et al. and Wang, et al. $[42,43]$ the inhibition of pathogens increased as the active compound (nicotine) in $N$. tabacum increased. Taiga, et al. [44] showed that $N$. tabacum cold extract inhibited the mycelia of $F$. oxysporum yam rot organism. The inhibition of $A$. ochraceus by $Z$. officinale may be attributed to the presence of an active ingredient called gingerol which acted against the growth of $A$. ochraceus in culture. Chohan and Perveen [45] inhibited the growth and spore germination of $F$. oxysporum and $F$. solani, causal agents of wilt and root rot, respective of tomato using Curcuma longa Val., Allium sativum L. and Zingiber officinale Rosc. Okigbo and Nneka [26] suppressed the growth of rot fungi in culture and reduce rot development in yam tubers using Z. officinale. The active compound papain in $C$. papaya may be responsible for its inhibitory activity [46] Suleiman [47] inhibited mycelial growth of Alternaria solani, causal organism of yam rot using leaf extracts of $C$. papaya while Chima [48] showed that leaf extracts of $C$. papaya contained phytochemical such as tannins, glycosides, alkaloids, and flavonoids that are responsible in controlling post harvest soft rot of yam caused by Rhizopus nigricans and Mucor circinelloides.

Effect of concentrations of $P$. guineense, Z. officinale, A.indica and chemical fungicide in controlling rot pathogens of Pepa tubers in storage for five months revealed that $P$. guineense, $Z$. officinale and $A$. indica extracts possess antimicrobial activities against rot pathogens of yam in storage at different concentrations. The results revealed that $60 \mathrm{~g} / \mathrm{L}$ and $90 \mathrm{~g} / \mathrm{L}$ were more effective than $30 \mathrm{~g} / \mathrm{L}$ of the extracts. The differences in the activities of the extracts may be due to the presence of secondary metabolites in these plants. Mean decay reduction index (DRI)for each of the plant extract and chemical fungicide on Pepa cultivar of white yam tubers tested showed mean values from 0.83 (P.guineense and $Z$. officinale), 0.93 ( $A$. indica) to 1.00 (mancozeb). This shows that the plant extracts reduced the occurrence of yam tuber rot disease by between $83 \%$ and $100 \%$ during storage of yam tubers for five months. This showed that only $17 \%$ of tubers treated with $P$. guineense and $Z$. officinale and $7 \%$ of tubers treated with $A$. indica extracts were lost to storage pathogens in the first year. The second year showed mean decay reduction index between 0.44 (Z. officinale) and 0.66 (A. indica) and 0.80 (mancozeb). This showed that the extracts controlled between $44 \%$ and $66 \%$ of rot pathogens and $80 \%$ of rot pathogens when mancozeb was used. This result disagreed with investigation obtained by Okigbo, et al. [11] who recorded high rot reduction of $62.80 \%$ using $A$. sativum to control pathogens of yam. Similarly, Udo, et al. [49] reduced the growth and sporulation of fungal pathogens on sweet potato and yam with garlic $(A$. sativum). The result also disagreed with findings of Aidoo [50] who used mancozeb to control yam tuber rot diseases of dente and pona and recorded decay reduction index of 0.46 and 0.60 respectively which implies that only $46 \%$ and $60 \%$ of rot pathogens were controlled in dente and pona respectively contrary to the $100 \%$ and $80 \%$ inhibition achieved in the first and second year, respectively.

\section{Conclusion}

The study demonstrated the potency of $A$. indica, $P$. guineense, Z. officinale, C. papaya and N. tabacum extracts against $A$. ochraceus in vitro and $A$. indica, $P$. guineense and $Z$. officinale against other yam rot pathogens in storage. The effectiveness of $A$. indica was more compared with $P$. guineense and $Z$. officinale on storage Pepa yam for five months both in the first and second year of storage. All the other extracts are also found to be effective and could be exploited for the management of $A$. ochraceus and other yam pathogens in storage since they are ecofriendly. The cheapness and availability of these plants will also make it possible for the development of natural plant protection products at the disposal of peasant farmers.

\section{Conflict of Interest Disclosure}

The authors declare that there is no conflict of interest regarding the publication of this paper.

\section{Funding Acknowledgement}

This research received no specific grant from any funding agency in the public, commercial or not-for- profit sectors.

\section{References}

1. Okigbo RN, Ogbonnaya UO (2006) Antifungal effects of two tropical plant leaves extract (Ocimum gratissimum and Aframomum melegueta) on post harvest yam (Dioscorea spp.) rot. Afr J Biotech 5(9): 727-731.

2. Food and Agricultural Organization (2013) Food and Agricultural Organisation of the United Nations. 


\section{Open Access Journal of Microbiology \& Biotechnology}

3. Food and Agriculture Organization (2008) Production Year Book, FAO, Rome.

4. Kleih U, Phillips D, Ogbonna M, Siwoku B (2012) Nigeria-Scoping Yam Value Chain Analysis. Yam Improvement for Income and Food Security in West Africa. ABK Publishers pp: 1-58.

5. Ogaraku AO, Usman HO (2008) Storage Rot of Some Yams (Dioscorea Spp) in Keffi and Environs, Nasarawa State, Nigeria. Journal of Production Agriculture and Technology 4 (2): 22-27.

6. Okigbo RN, Agbata CA, Echezona CE (2010) Effect of leaf extract of Azadirachta India and Chromolaena odorata on post harvest spoilage fungi of yams in storage. Current Res J of boil Sci 2(1): 9-12.

7. Ayanwuyi E, Akinboye AO, Oyetoro JO (2011) Yam Production in Orire Local Government Area of Oyo State, Nigeria: Farmer's Perceived Constraints. World Journal of Young Researchers 1(2): 16-19.

8. Okigbo NR, Enweremadu CE, Agu CK, Irondi RC, Okeke BC, et al. (2015) Control of white yam (Dioscorea rotundata) rot pathogen using peel extract of water yam (Dioscorea alata). Advances in Applied Science Research, 6(10): 7-13.

9. Gwa VI, Akombo RA (2016) Studies on the Antimicrobial Potency of Five Crude Plant Extracts and Chemical Fungicide in in vitro Control of Aspergillus flavus, Causal Agent of White Yam (Dioscorea rotundata) Tuber Rot. Journal of Plant Sciences and Agricultural Research 1(1): 1-8.

10. Gwa VI, Nwankiti AO (2017). Efficacy of some plant extracts in in-vitro control of Colletotrichum species, causal agent of yam (Dioscorea rotundata Poir) tuber rot. Asian Journal of Plant Science and Research 7(2): 8-16.

11. Okigbo RN, Putheti R, Achusi CT (2009) Post-harvest deterioration of cassava and its control using extracts of Azadirachta indica and Afromonium meleguata. E J Chem 6(4): 1274-1280.

12. Okigbo RN, Ikediugwu FEO (2000) Studies on biological control of post-harvest rot of yams (Dioseorea spp) with Trichoderma viride. J Phytopathol 148(6): 351-355.
13. Okigbo RN (2005) Biological Control of Postharvest Fungal Rot of Yam (Dioscorea spp.) with Bacillus subtilis. Mycopathologia 159(2): 307-314.

14. Arinze AE (2005) Plant Pathology and Post -harvest Food Loss. An Inaugural Lecture Series 43: 1-101.

15. Okigbo RN, Anuagasi CL, Amadi JE (2009) Advances in Selected Medicinal and Aromatic Plants Indigenous to Africa. Journal of Medicinal Plant Research 3(2): 86-95.

16. Sadiku NA, Sadiku IBS (2011) Indigenous Efforts by African Farmers in Ensuring Sustainability in Agricultural Productivity in the face Changing Climate: A Proceeding of the Environmental Management Conference, FUNAAB, Nigeria, Pp: 6472.

17. Kumar AS, Reddy NPE, Reddy KH, Devi MC (2007) Evaluation of Fungicidal Resistance Among Colletotrichum gloeosporioides isolates Causing Mango Anthracnose in Agric. Export Zone of Andhra Pradesh, India. Plant Pathology Bulletin 16(3): 157160.

18. Malkhan SG, Shahid A, Masood A, Kangabam SS (2012) Efficacy of plant extracts in plant disease management. Agricultural Sciences 3(3): 425-433.

19. Gwa VI, Ekefan EJ (2017) Fungal Organisms Isolated from Rotted White Yam (Dioscorea rotundata) Tubers and Antagonistic Potential of Trichoderma harzianum against Colletotrichum Species. Agri Res Tech Open Access J 10(3): 1-10.

20. Gwa VI, Abdulkadir KH (2017) Biological Control Using Trichoderma harzianum against Penicillium purpurogenum, Causal Agent of White Yam Tuber (Dioscorea rotundata Poir) Rb. J Biores Commun 1(1): 1-6.

21. Gwa VI, Nwankiti AO (2017b) In Vitro Antagonistic Potential of Trichoderma harzianum for Biological Control of Fusarium moniliforme isolated from Dioscorea rotundata Tubers. Virol mycol 6(2): 1-8.

22. Gwa VI, Ekefan EJ, Nwankiti AO (2017) Antifungal Potency of Some Plant Extracts in the Control of White Yam (Dioscorea rotundata poir) Tuber Rot. Adv Biotech Micro 7(1): 1-7. 


\section{Open Access Journal of Microbiology \& Biotechnology}

23. Nwankiti AO, Gwa VI (2018) Evaluation of Antagonistic Effect of Trichoderma Harzianum against Fusarium oxysporum causal Agent of White Yam (Dioscorearotundata poir) Tuber Rot. Trends Tech Sci Res 1(1): 1-7.

24. Bediakao A, Showemimo FA, Asiamo YO, Amewowor DHAK (2007) In vitro Analysis of Growth Media and the Control of Yam Minisett-rot. Biotechnology 6(1): 40-44.

25. Sani S, Gwa VI (2018) Fungicidal Effect of Azadiracta Indica and Zingiber Officinale Extracts in the Control of Fusarium Oxysporum and Rhizoctonia Solani on Tomato (Solanum Lycopersicum) Fruits. Innovative Techniques in Agriculture 2(4): 439-448.

26. Okigbo RN, Nneka IA (2005) Control of Yam Tuber with Leaf Extracts of Xylopia aethiopica and Zingiber officinale. African Journal Biotechnology 4 (8): 804807.

27. Ahmed KM, Ravinder Reddy Ch (1993) A pictorial guide to the identification of seed borne fungi of sorghum, pear millet, finger millet, chickpea, pigeonpea and groundnut. Information Bulletin no. 34. Internation Crops Research Institute for the Semi Arid Tropics, Pp: 200.

28. Agrios G (2004) Plant pathology $5^{\text {th }}$ (Ed.), Elsevier, London.

29. Amadioha AC, Obi VI (1999) Control of anthracnose disease of cowpea Cymbopogon citratus and Ocimum gratissimum. Acta phytopathol Entomol Hungerica 34(92): 85-89.

30. Korsten L, Nene ZH, Thapilyal (2002) Management of mushroom pathogens through botanicals. Ind Phytopathol 58:189-193.

31. Vedashree S, Sateesh MK, Lakshmeesha TR, Sofi MS, Vedamurthy $A B$ (2013) Screening and assay of extracellular enzymes in Phomopsis azadirachtae causing die-back disease of neem. J Agricultural Technol 9(4): 915-927.

32. Gomez KA, Gomez AA (1984) Statistical Procedures for Agricultural Research $2^{\text {nd }}(E d n)$, John Wiley and sons Pp: 680.
33. Amadioha AC (1996) Control of storage rot of potato caused by Rhizopus oryzae. International journal of Pest Management 42(4): 311-324.

34. Cochran GW, Cox GM (1992) Experimental Designs. $2^{\text {nd }}($ Edn.), John willey and Sons Inc, Pp: 611.

35. Ogunleye AO, Ayansola OT (2014) Studies of Some Isolated Rot-Causing Mycoflora of Yams (Dioscorea Spp.). Amer J Microb Biot 1(1): 9-20.

36. Taiga A (2012) Differential Rate of Dry Rot in Dioscorea rotundata (White Yam) along the Tuber Length Due to Rot Causing Fungi. Advances in Microbiology 2(4): 452-455.

37. Biu AA, Yusuf SD, Rabo JS (2009) Phytochemical Screening of Azadirachtaindica (Neem) (Meliaceae) in Maiduguri, Nigeria. Bioscience Research Communications 21(6): 281-283.

38. Aidah N, Abdullah N, Oskoueian E, Sieo CC, Saad WZ (2014) Membrane-Active Antibacterial Compounds in Methanolic Extracts ofjatropha curcas and their Mode of Action against Staphylococcus aureus S1434 and Escherichia coli E216. Int J Agric Biol 16(4): 723-730.

39. Hycenth N (2008) Effect of Different Plant Extracts in the Control of Yam Rot Induced by Rhizopus stolonifer on Stored Yam (Dioscorea sp.) in Yola, Adamawa State Nigeria. Agricultural Journal 3 (5): 382-387.

40. Oluma HOA, Elaigwe M (2006) Antifungal activity of extracts of some medicinal plants gainst Macrophomina phaseolina. Journal of Botany 19(1): 121-28.

41. Ijato JY (2011) Antimycotic effects of aqueous and ethanol plant extracts on yam rot pathogens in AdoEkiti, Nigeria. Academia Arena 3(1): 115-119.

42. Suresh K, Saravana Babu S, Harisaranraj R (2008) Studies on In Vitro Antimicrobial Activity of Ethanol Extract of Rauvolfia tetraphylla. Ethnobotany Leaflets 12: 586-590.

43. Wang H, Zhao M, Yang B, Jiang Y, Rao G (2008) Identification of Polyphenols in Tobacco Leaf and their Antioxidant and Antimicrobial Activities. Food Chemistry 107(4): 1399-1406.

44. Taiga A, Suleiman MN, Sule W, Olufolaji DB (2008) Comparative in vitro inhibitory effects of cold 
extracts of some fungicidal plants on Fusarium oxysporium Mycelium. African Journal of Biotechnology 7(18): 3306-3308.

45. Chohan S, Perveen R (2015) Phytochemical analysis and antifungal efficacy of rhizome extracts of various plants against fusarium wilt and root rot of tomato. Int J Agric Biol 17: 1193-1199.

46. Cowan MM (1999) Plant Products as Antimicrobial Agents. Clin Microbiol Rev 12(4): 564-582.

47. Suleiman MN (2010) Fungitoxic Activity of Neem and Pawpaw Leaves Extracts on Alternaria Solani, Causal Organism of Yam Rots. Advances in Environmental Biology 4(2): 159-161.
48. Chima N (2012) Antifungal Potencies of Leaf Extracts of Carica papaya on Fungi implicated in Soft Rot of Yam. Annals of Food Science and Technology 13(2): 202-209.

49. Udo SE, Madunagu BE, Isemin CD (2001) Inhibition of growth and sporulation of fungal pathogens on sweet potato and yam by garlic extracts. Nigeria Journal of Botany 14: 35-39.

50. Aidoo KA (2007) Identification of yam tuber rots fungi from storage systems at the Kumasi Central market. A dissertation submitted to Faculty of Agriculture, KNUST, Pp: 250. 